This is an open access article under the CC BY-NC-ND license (https://creativecommons.org/licenses/by-nc-nd/3.0/) Issue III, November 2020

ISSN 2707-9481

ISBN 978-601-323-207-2

https://doi.org/10.31643/2020.006

\author{
Arapbek Aitzhanov \\ Abai Kazakh National Pedagogical University, Kazakhstan \\ E-mail: arapbek_86-86@mail.ru \\ ORCID ID: 0000-0003-1164-2431
}

\title{
Teacher's views on updated education in the Republic of Kazakhstan
}

\begin{abstract}
The article points out that teachers need to prepare graduates for the school, such as creative, social responsibility, developed intelligence, high levels of professional literacy, and a constant motivation for cognitive activity, following the orders of the community. The author also believes that the transition to educational content updating is the introduction of new work conditions. We need to be prepared to work with our age-appropriate competencies while providing educators with health technology. Updating the education system is a transition to a new, more inclusive model of developing, multi-disciplinary education that provides traditional reproductive learning styles and cognitive activity and students' independent thinking. In the research, the author emphasizes that the proposed education renewal program should be conducted in an active, collaborative environment, with a focus on education, and with interdisciplinary communications.
\end{abstract}

Keywords: motivation, education, teacher, formation, learner.

Cite this article as: Aitzhanov A. (2020), Qazaqstan Respublikasındağı jañartılğan bilim beru mazmunına muğalimniñ közqarası [Teacher's views on updated education in the Republic of Kazakhstan], Challenges of Science. Issue III, 2020. Pp.: 42-46. https://doi.org/10.31643/2020.006

\author{
Арапбек Айтжанов \\ Абай ат. ҚазҰПУ магистранты \\ E-mail: arapbek_86-86@mail.ru \\ ORCID ID: 0000-0003-1164-2431
}

\section{Қазақстан Республикасындағы жаңартылған білім беру мазмұнына мұғалімнің көзқарасы}

\begin{abstract}
Абстракт: Автор мақалада мұғалімдер қоғамның бұйрығын орындай отырып, мектеп ішінде шығармашылық, әлеуметтік жауапкершілік, дамыған ақылға ие болу, кәсіби сауаттылықтың жоғары деңгейі, танымдық іс-әрекеттің тұрақты мотивациясы сияқты түлектерді даярлау қажеттігін айтады. Сонымен қатар, автор білім беру мазмұнын жаңартуға көшу жаңа жұмыс талаптарын ұсыну деп біледі. Білімге құзіреттілік негізінде, тәрбиешілерді денсаулық сақтау технологиясымен қамтамасыз ете отырып, жас ерекшеліктеріне сай жұмыс істеуге дайын болу қажет. Білім беру құрылымын жаңарту - бұл дәстүрлі репродуктивті оқыту стилін және оқушылардың танымдық белсенділігі мен дербес ойлауын қамтамасыз ететін дамушы, сындарлы білім берудің жаңа моделіне көшу. Зерттеу барысында автор қарауға ұсынылған білім беруді жаңарту бағдарламасы білім беру белсенді, бірлескен ортада жүргізілуі керек, білім беруді саралау жүргізілуі керек, іске асыру барысында пәнаралық байланыстар жүзеге асырылуы керек екендігін баса айтады.
\end{abstract}

Түйін сөздер: мотивация, білім, мұғалім, қалыптастыру, оқушы. 


\section{Kiрicпе}

Қазіргі Қазақстанда әлемдік білім беру кеңістігіне бағытталған жаңа білім беру жүйесі дамуда. Бұл процесс педагогикалық теория мен практикада айтарлықтай өзгерістермен бірге жүреді. Мен, бес жылдық тәжірибесі бар мұғалім, осы мақалада трансформация идеясының пайда болу себептері туралы өзімнің көзқарасыммен бөліскім келеді. Біздің өміріміздің кез-келген саласында, тіпті білім берудегі сапалы өзгерістер мұғалімнің оның оқу-тәрбие үрдісіндегі орны мен рөлі туралы жаңа көзқарасын қалыптастырусыз мүмкін емес. Біз, мұғалімдер, жаңартылған білім мазмұны мен технологиясындағы жаңа мақсаттар мен міндеттерді, оқытудың құзіреттілік тәсілін ескере отырып, бағалаудың жаңа формаларын түсінбестен, бұл мүмкін емес шығар. Сондықтан мұғалімге жалпы орта білім берудің жаңартылған МЖББС әдістемесі мен мазмұнын қабылдауға, оқу үрдісін бағдарламалық және әдістемелік қамтамасыз етуді өзгертуге, педагогикалық қызметтің мақсаттары мен әдістерін өзгертуге дайын болу қажет.

Зерттеу нәтижесі

Әріптестермен сөйлесе отырып, мен қазіргі уақытта әр мұғалім мен мені қызықтыратын сұрақтарға жауап алдым:

- Жаңартылған білім беру мазмұны мен қазіргі заманның айырмашылығы неде?

- Мектептегі оку процесін ұйымдастыруға көзқарастар өзгере ме?

- «Нәтижеге бағытталған білім» түсінігі нені білдіреді?

- Білім берудің жаңартылған мазмұнына мұғалім қай бағытта және қалай дайындалуы керек?

- Қазіргі уақытта біз білім беру процесінің технологиялық дамуы, осы немесе басқа педагогикалық инновациялық технологияларды енгізудің артықшылықтары туралы көп сөйлесеміз. Біз оларды игереміз, оларды оқу процесінде қолданамыз, белгілі бір нәтиже аламыз, бірақ көптеген мәселелер бар. Біз өзімізден оқушылардың ынтасын қалай арттыруға болады?

- Мектептегі адамның адамгершілік және рухани қасиеттерін: өзін-өзі тану, өзін-өзі анықтау және өзін-өзі тануды дамытуды ынталандыратын адамгершілік білім беру ортасын құруға не ықпал етеді?

- Білім беру жүйесіндегі әлемдік дамудың негізгі бағыттары:

- қоғамның даму қарқынын жеделдету; - постиндустриалды, ақпараттық қоғамға көшу, мәдениаралық өзара іс-қимылды кеңейту;

- халықаралық ынтымақтастық нәтижесінде шешілетін ғаламдық проблемалардың пайда болуы және өсуі;

- қоғамды демократияландыру;

- экономиканың қарқынды дамуы, бәсекелестіктің артуы;

- адами капиталдың өсіп келе жатқан маңыздылығы.

Өзін халықаралық деңгейде сенімді түрде жариялап келе жатқан біздің дамып келе жатқан республикамыз осы үрдістердің ықпалынан тыс қала алмайды. Біздің қоғамның өзекті мәселелерінің бірі білім саласыны инновациялық әдістерді кіріктіру [1-10] болып табылады. Бұл өзгеріп отырған әлеуметтік-экономикалық жағдайларда өмір сүруге ғана емес, сонымен бірге бар шындықты жақсы жаққа өзгерте отырып, белсенді әсер етуге дайын бәсекеге қабілетті жеке тұлға қалыптастыру.

Осыған байланысты біз мұғалімдер қоғамның бұйрығын орындай отырып, мектеп ішінде шығармашылық, әлеуметтік жауапкершілік, дамыған ақылға ие болу, кәсіби сауаттылықтың жоғары деңгейі, танымдық іс-әрекеттің тұрақты мотивациясы сияқты түлектерді даярлауымыз керек. Білім беру мазмұнын жаңартуға көшу жаңа жұмыс талаптарын ұсынады. білімге құзіреттілік негізінде, тәрбиешілерді денсаулық сақтау технологиясымен қамтамасыз ете отырып, жас ерекшеліктеріне сай жұмыс істеуге дайын болу АҚШ-тың білім беру процесін дараландыру. Білім беру құрылымын жаңарту - бұл дәстүрлі репродуктивті оқыту стилін және оқушылардың танымдық белсенділігі мен дербес ойлауын қамтамасыз ететін дамушы, сындарлы білім берудің жаңа моделіне көшу. Қарауға ұсынылған білім беруді жаңарту бағдарламасы білім беру белсенді, бірлескен ортада жүргізілуі керек, білім беруді саралау жүргізілуі керек, іске асыру барысында пәнаралық байланыстар жүзеге асырылуы керек.

Жоғарыда айтылғандардан басқа АКТ, интерактивті оқыту, зерттеу әдістері және оқушылардың қажеттіліктеріне уақытылы жауап беру міндетті. Жоғарыда айтылғандардың бәрінен жаңартылған білім беру мазмұны бағдарламасында жұмыс жасайтын мұғалімнен не талап етіледі? Бұл шеберлік: 
- нәтижеге жету үшін оқу мақсаттарын тұжырымдау; - оқу материалын игеруді ұйымдастыру үшін оқу процесін құру; - оқу мақсатына сәйкес оқу материалдарын дайындау;

- білім беру процесі үшін ақпараттық ортаның әлеуетін пайдалану;

- студенттердің тұлғалық және белсенді бағытта қарқынды дамуына жағдай жасау;

- психологиялық жайлылық пен қолдау атмосферасын құру; дайындайды;

- студенттерді өзін-өзі тәрбиелеуге, өзін-өзі анықтауға және өзін-өзі жүзеге асыруға

- қойылған мақсаттарға жетуге бағытталған ағымдағы нәтижелерді бағалау. Мұғалім жаңартылған мазмұнға сәйкес қалыптасқан құзыреттердің жоғары деңгейіне ие болуы керек:

Арнайы құзіреттілік - кәсіби қызметпен жеткілікті дәрежеде шұғылдану және олардың әрі қарай кәсіби дамуын жоспарлау мүмкіндігі;

Әлеуметтік құзіреттілік - бірлескен (ұжымдық, топтық) кәсіптік қызметпен айналысу, бірлесіп жұмыс жасау және кәсіпте қабылданған кәсіби қарым-қатынас әдістерін қолдану мүмкіндігі;

Тәрбиелік құзіреттілік - кәсіби білім мен дағдыны дамытуға қызығушылық, оқу іс-әрекетінде мақсат қою, оку іс-әрекетінде субъективтілік пен шығармашылықты дамыту, педагогикалық және әлеуметтік психология негіздерін қолдана білу. Жаңа бағдарлама аясында қазіргі студент қандай болуы керек?

- білім берудің жеке траекториясын құру мүмкіндіктерін пайдалану (қарқыны, оқу материалының деңгейі);

- өз жұмысының дағдыларын, әдістерін, техникаларын үйренеді;

- білім, дағдыны және қолда бар ақпаратты оқу жағдайларын шешу үшін пайдалану.

Дамыған ортада өмір сүруге қабілетті, өзінің мүдделері үшін де, қоғам мүдделері үшін де өзін-өзі көрсетуге дайын білімді, шығармашыл, құзыретті және бәсекеге қабілетті тұлғаны қалыптастыру және дамыту.

Мақсатқа сәйкес білім берудің күтілетін нәтижелері түлектің келесі негізгі құзіреттіліктері түрінде анықталады: Құндылыққа бағытталған құзыреттілік - оқушының әртүрлі өмірлік жағдайларда шешім қабылдауға қабілеттілігі. Ең бастысы - өз Отаның - Қазақстанның патриоты болу.Мәдени құзіреттілік - жалпыадамзаттық мәдениеттің жетістіктері мен ұлттық сипаттамаларға негізделген білім мен тәжірибеге ие болу, өз халқының мәдениетін және әлемнің мәдени әртүрлілігін бағалау; рухани келісім мен толеранттылық идеяларына адал болу.

Оку-танымдық құзіреттілік - оқушының дербес оку, танымдық және зерттеу іс-әрекеті процесін қамтамасыз ету. Коммуникативті құзіреттілік ана тілін және басқа тілдерді білуді, қазақ тілінде қарым-қатынас дағдыларын мемлекеттік тіл ретінде, халықаралық қатынас-орыс тілінде, шет тілдерінде меңгеруді қамтиды.Бастауыш сынып мұғалімі ретінде мен жаңартулардың бастауыш білім деңгейіне қаншалықты әсер ететіндігі қызықтырды. Осыған байланысты білім мазмұнын жаңарту жағдайында мектепке дейінгі тәрбие мен оқыту деңгейі ерекше мәнге ие болады. 5 жастағы балаларға арналған мектепке дейінгі даярлық психологиялық, педагогикалық, физикалық, физиологиялық талаптарды ескере отырып жүргізілуі керек, бұл балалардың бастауыш мектепке дайындық сапасының негізгі шарты болып табылады.

Орта жалпы білім берудің 1 кезеңі (1-4 сыныптар ).Оқытудың басталу жасы - 6 жыл. Оқу ұзақтығы - 4 жыл, 1 кезеңнің негізгі мақсаты - оқушының жеке басын ашу және өзін-өзі тану, қоршаған шындық туралы білімді түсіну, білім алуға деген ықыласы мен қабілеттерін қалыптастыру. білім берудің келесі деңгейлерінде қажет шынайы танымдық уәждемені құру, кіші студенттерде тұтас тәрбиелік әрекеттерді қалыптастыру. Баланың жеке басының қалыптасуын, оның қабілеттерін жан-жақты дамытуды қамтамасыз ету. Бастауыш мектепте оқу іс-әрекетін ұйымдастыру, қажетті дағдыларды алуға, оку, жазу, санау дағдыларына баулу, шығармашылық ойлау элементтерін, жеке бас гигиенасы мен денсаулықты сақтау негіздерін игеру.

Окушылардың күтілетін нәтижелерін бағалау жүйесін өзгертуге көп көңіл бөлінеді. Бағалау келесі принциптерге сәйкес келуі керек:
$>$ Жүйелік Кезектілік
$>$ Объективтілік
$>$ Ашықтық
$>$ Сенімділік

Ол бағалаудың екі бағытын параллель дамытуды көздейді: (қалыптастырушы және жиынтық бағалау) Нәтижеге бағдарланған білім беру моделіндегі оқу жетістіктерін бағалау тоқсандағы сабақтың және қорытынды жұмыстың нәтижелеріне негізделген бағалау әдістерін қамтиды. 
Біз, мұғалімдер ретінде, қазіргі әлемде бейімделе алатын және жүзеге асыра алатын осындай студенттерді оқыту мен тәрбиелеудің маңызды міндетіне тап боламыз. Егер мұғалімнің өзі тез өзгеріп жатқан әлем жағдайларына дайын болмаса, бұл мақсатқа жету мүмкін емес. Мен үшін қазір сұрақ туындайды: мұндай «білім шыңына» «шабуылға» қалай дайындалу керек? Мен мұны жасай аламын ба? Өйткені, менде үлкен жауапкершілік болады!

Мен жаттығуды өзімді жаңартылған бағдарламамен таныстырудан бастадым. Бағдарламаны зерттей келе, ол жаңартылған бағдарламаға көшу бүкіл білім беру жүйесін жаңартуды қажет ететіндігін айтты. Мұндай ауысуды жүзеге асыру үшін өзгерістерді өзінен, яғни мұғалімнен бастау керек. Ұстаз, менің түсінігім бойынша - жасампаз. Зергер кәсібінің қаншалықты күрделі екенін бәрі біледі.

Оның жұмысының күрделілігі гауһарға бетті қолданудан тұрады. Бірақ мұғалім - бұл зергер, оған керісінше мұғалімнің қолында баға жетпес қазына бар - бала. Жұмыстың нәтижесі осы кәсіптерді біріктіреді: зергерде сан алуан гауһар бар, ал мұғалім жан-жақты дамыған жеке тұлғаға ие. Қандай аспект болады, көбінесе мұғалімнің құзыретіне байланысты.

Менің «білім шыңын» бағындырудағы «алғашқы дұрыс қадамдардың» бірі бастауыш сынып мұғалімдеріне арналған орта білім мазмұнын жаңарту бағдарламасында үздіксіз білім беру курстарының аяқталуы болды. Менің ойымша, бұл курстардың негізгі мақсаты - қазақстандық мұғалімдерге педагогикалық практиканы жетілдіруге көмектесу, ақпарат көзі ретінде емес, студенттің өзі білетін білімді «бағыттаушы» ретінде жұмыс істеуге үйрену.

Біз курстарға енгізілген жаңартылған бағдарламаның нәтижесі студенттердің өз бетінше оқуды үйренуі және нәтижесінде тәуелсіз, өзін-өзі ынталандыратын, ынталы, сенімді, жауапты, сыни тұрғыдан ойлау қабілеті дамыған, орыс тілінде еркін сөйлей алатын студенттер бола алады. Сандық технологияларды білетін қазақ және ағылшын тілдері

Маған жаңартылған бағдарлама ұнайды, өйткені сабақта алған білімді қолдана отырып, жаңасын іздеу үнемі жалғасады, оған мұғалім де, бала да қатысады. Менің ойымша, бұл баламен қарым-қатынастан және жұмыста қанағаттанушылық пен куаныш әкеледі.

Ал мектепте бір жылдан астам уақыт жұмыс істеген мұғалім ретінде білім берудегі өзгерістерді байқаймын. Оку процесінде, жаңартылған бағдарламаға сәйкес, балалар ұсынылған тапсырмаларды шешуде креативті болуға, шығармашылық тұрғыдан ойлауға, өзіне жүктелген тапсырмалардың стандартты емес шешімдерін табуға мүмкіндік алады.

Мұғалім баланың не ойлайтынын түсіне алады. Жұмыстың жаңа формалары мен әдістері пайда болды: топтық жұмыс, жұптық жұмыс және т.б. Балаларды мектепте оқытудың нәтижелері бізден, мұғалімдерден әр оқушының күтілетін оқу нәтижелеріне жетудегі табысты жан-жақты және объективті бағалауды, оның оқуға деген көзқарасы мен жалпы тұлғаның даму динамикасын талап етеді, бірақ білім мазмұнын жаңарту, оқыту мен оқытудың жаңа тәсілдерін енгізудегі ең жақсы тәжірибені тарату дәстүрдің оң тәжірибесін ескеруі керек.

Оқытудың дәстүрлі және инновациялық әдістерінің синтезі оқушылардың танымдық белсенділігін жандандыратын сабақтардың түрлерін әртараптандырады.Қазақстанның орта жалпы білім деңгейі мемлекеттің даму мақсаттарына сәйкес келуі және қазіргі әлемде оның бәсекеге қабілеттілігін қамтамасыз етуі керек.

\section{Қорытынды}

Қорытындылай келе, мен «Орта білім мазмұнын жаңарту» деп аталатын «білім шыңын» жеңіп алу үшін Қазақстанға тұрақтылық пен өркендеуді, осы мектептің талантты және табысты мұғалімдері мен оқушыларына, сондай-ақ өзіме және менің әріптестеріме осындай қарапайым жұмыста жеңіс тілеймін. шығармашылық табыс!

Мақалаға сілтеме: Айтжанов А. (2020), Қазақстан Республикасындағы жаңартылған білім беру мазмұнына мұғалімнің көзқарасы. Challenges of Science. Issue III, 2020. Рp.: 42-46. https://doi.org/10.31643/2020.006

\section{Refrences}

[1]. Retnawati H., Sulistyaningsih E., Rasmuin R. (2020), How to Teach Mathematical Concept Easily? (Learning Trajectory of Two-Variable Linear Equation System Topic in Junior High School). Challenges of Science. Issue III, 2020. Pp.: 5-13. https://doi.org/10.31643/2020.001

[2]. Fauzi, C., Basikin, Duisenbayeva, S., Kassymova, G. (2020). Exploring EFL Students Teacher Readiness and Gender 
Differences of Learner Autonomy. Bulletin the National Academy of Sciences of the Republic of Kazakhstan, 1(383), 288-299. https://doi.org/https://doi.org/10.32014/2020.2518-1467.34

[3]. Kenzhaliev B.K., Kul'deev E.I., Luganov V.A., Bondarenko I.V., Motovilov I.Y., Temirova S.S. (2019). Production of Very Fine, Spherical, Particles of Ferriferous Pigments from the Diatomaceous Raw Material of Kazakhstan. Glass and Ceramics, 76(5-6), 194-198. https://doi.org/10.1007/s10717-019-00163-w

[4]. Lavrinenko S. V., Gorelova I. V., Kassymova K. G., Kubantseva O. V., Khudyakova T. L., Yusipova I. V., Arpentieva M. R. (2020). Problems of context and conceptual management in education: psychological, social and economical aspects. Bulletin the National Academy of Sciences of the Republic of Kazakhstan, 1(383), $264-276$. https://doi.org/10.32014/2020.2518-1467.32

[5]. Atayeva, M., Ciptaningrum, D. S., Hidayah, R., Kassymova, G. K., Dossayeva, S. K., Akmal, A. (2019). Cultivating Junior High School Students' Critical Thingking Skills by Using a Short Video in English Language Classroom. Bulletin the National Academy of Sciences of the Republic of Kazakhstan, 5(381), $57 \quad-\quad 69$. https://doi.org/https://doi.org/10.32014/2019.2518-1467.124

[6]. Arpentieva, M. R., Kassymova, G., Kenzhaliyev, O., Retnawati, H., Kosherbayeva, A. (2019). Intersubjective Management in Educational Economy. Challenges of Science. https://doi.org/10.31643/2019.004

[7]. Atayeva, M., Putro, N. H. P. S., Kassymova, G., Kosbay, S. (2019). Impact of reading on students' writing ability. Challenges of Science. https://doi.org/10.31643/2019.001

[8]. Kassymova, G. (2018). Competence and its implications. Challenges of Science. https://doi.org/10.31643/2018.063

[9]. Triyono, B.M., Mohib, N., Kassymova, G.K., Pratama, G.N.I.P., Adinda D., Arpentieva, M.R. (2020). The Profile Improvement of Vocational School Teachers' Competencies. Vysshee obrazovanie v Rossii = Higher Education in Russia. Vol. 29, no. 2, pp. 151-158. https://doi.org/10.31992/0869-3617-2020-29-2-151-158

[10]. Aitzhanov A. (2020), Role of Education Assessment for Education Management. Challenges of Science. Issue III, 2020. Pp.: 27-26. https://doi.org/10.31643/2020.003 